considers that the new region should also include Durham, partly to avoid Tyneside, as an industrial region, being swamped by a conservative and agricultural county, which has not yet shown itself to possess industrial standards in its social services, and partly because of Durham's achievements in the development of such services, and he also points out the example set by some of the districts such as Felling in changing their character from a slum-ridden overcrowded little town to one of the best garden cities in the country. If such districts lose control of their own civic life the division of powers between local and regional authorities will require the closest consideration to avoid friction or deadlock, and $\mathrm{Mr}$. Goodfellow advocates the transfer of control of all services and ownership of all public utilities to the regional authority as most conducive to social development.

\section{Conflicting Ideals and War Aims}

ON the outbreak of war, the -ologies and -isms into which the world of European civilization had been divided since the irruption of the dictator into national and international politics were resolved into an opposition of Christianity over against paganism. Such at least has been the rallying cry with which Britain, in what may be termed her official proclamations, asks for and has received the moral and material support of the members of the British Commonwealth of Nations, the United States of America and the remaining free peoples of the world. It must be patent, however, that in the present stage of development of modern thought, a literal interpretation of this bond as a subscription to a theological formula, as would seem to be implied, would set outside the pale not only those who are members of the other great religious systems of the world, but also those who, while intellectually 'non-jurors', have entered upon the struggle to secure the ascendancy in world affairs of that spirit which inspires Christianity, but is not peculiar to it, with a fervour and passionate devotion which has all the intensity of religious emotion. To say this is not to imply a revival of the over-long opposition of religion and science. It is rather to emphasize what has been in fact an approach to composing their differences; but there are not lacking those who in the cause of intellectual integrity would prefer to clarify the issue and to rest upon a statement of our aim in its simplest and widest appeal as being alone acceptable to those who adopt the point of view of the rationalist.

Such a line of argument is set out, for example, by Mr. A. Gowans Whyte in "Make your own Religion" (The Thinker's Forum, London, Watts and Co., 1940. Pp. 47. 6d.). After passing in review the evidences of the failure of Christianity-unkindly drawn in part from the utterances of the Churches themselves-and the bankruptcy of a Christianity which alternatively depends upon a few generalized moral principles, Mr. Whyte sets out on "an adventure" towards a new religion, a religion which is "a search for the truth" and "the satisfaction of the will to know" as opposed to "the will to believe".
The object of this "will to know" is the building up of a picture of the universe and man's place in it in accordance with the doctrines of evolution. Christian morality, it is argued, is not far and away superior to all other codes as the Divine law, but is as imperfect as those other codes and is subject to change in form from time to time and from place to place. The ideal on this view-a moral system which enables the individual to live " $a$ full mental, emotional and physical life in harmonious association with others equally blessed"-is, it is admitted, still a long way ahead, but progress will depend upon knowledge of the moral evolution of mankind and upon a mind set free "to learn, to probe, no doubt, to reject, to accept, as experience and reason suggest"--in other words upon the principle of freedom of thought for which really we are fighting.

\section{Additions to the British Flora}

Although only an infinitesimal proportion of the alien plants which reach Great Britain in some form or other and take root ever succeed in establishing themselves, much less colonizing the country, a small number of additions to the flora that have established themselves in recent years from garden escapes or alien casuals of industry may have some important bearing upon the flora of the future. In 1928, F. W. Holder and R. Wagstaffe, of the Southport Scientific Society, found an alien composite with small yellow flowers at Freshfield, West Lancashire (vice county 59, botanically "South" Lancashire), which Druce afterwards identified as Siegesbeckia orientalis, fairly widely distributed in the southern hemisphere, but not previously recorded in Britain. In the twelve years since then, the species has firmly established a colony of plants at the Freshfield station and J. D. Massey, in a communication to the Liverpool Botanical Society, has pointed out that it differs from Ridley's description of the species in the "Dispersal of Plants Throughout the World" in growing much taller (5-6 ft.), in always possessing five long narrow bracts instead of four, and has glands on the leaves and stem as well.

About the same period, R. E. D. Baker discovered Scirpus americanus (Pers) by a slack on the Freshfield dunes, its only other European station being on Jersey, although W. G. Travis had an unnamed 1909 specimen from the same Freshfield site in his herbarium. Since then, the colony of Scirpus americanus has considerably extended on the site to about half an acre, and J. D. Massey has successfully transplanted a second colony 100 yards south. The steady colonization of the countryside by such Petasites garden escapes as the winter heliotrope and white butterbur $(P$. albus) may be emulated by another white butterbur, Petasites japonicus, which was recently added to the Cheshire flora (Eric Hardy, J. Bot., April 1940). Wilson has noted it in Lakeland ("Flora of Westmorland"), and the former record elicited specimens in the British Museum herbarium from additional stations at Denham and Langsdale, and elsewhere from Denbighshire (Field, August 28). 